\title{
Toward a Process Model of Venture Capital Emergence: The Case of Botswana
}

\author{
David Lingelbach \\ Stevenson University and Johns Hopkins University \\ Evan Gilbert \\ University of Stellenbosch
}

\begin{abstract}
Venture capital (VC) is concerned with seed, startup, and early stage investing in firms involved with innovative products or processes. Existing variance studies of $\mathrm{VC}$ provide an incomplete understanding of $\mathrm{VC}$ emergence, emphasizing either macro-level enabling conditions or the efficient fund-level operation of the VC cycle. Following Tsoukas and Chia (2002), our study focuses on the non-prototypical portion of the VC phenomenon, which is found in weak institutional environments characteristic of many developing countries. In these contexts, $\mathrm{VC}$ is more likely to be an unstable organizational form and hence subject to change. As a consequence, new VC forms and emergence processes may arise in these environments, providing data in support of a more complete, processual model of $\mathrm{VC}$ emergence.
\end{abstract}

This paper reports findings of an exploratory case study of the $\mathrm{VC}$ emergence process in Botswana. Our main contribution is to develop a multi-stage process model of VC emergence. Our model consists of four processes: simultaneity (enabling), coproducing (bonding), diffusing, and replicating via the $\mathrm{VC}$ cycle. This model suggests that the establishment of appropriate simultaneity conditions - capital, entrepreneurs and specialized financial institutions - enables the diffusion of $\mathrm{VC}$ models and related institutions from other populations. In the presence of an equity gap, government investors and private fund managers need to then cooperate to fill the equity gap, creating the signal necessary for replication of $\mathrm{VC}$ funds through the operation of the $\mathrm{VC}$ cycle.

We also contribute to the $\mathrm{VC}$ literature by showing that the diffusion of $\mathrm{VC}$ models and related institutions from other populations plays an intermediate role in the emergence process, following the establishment of simultaneity conditions, paralleling coproduction between government investors and fund managers, and preceding the operation of the $\mathrm{VC}$ cycle. The resulting model provides a more complete understanding of the $\mathrm{VC}$ emergence process and augments existing theoretical perspectives by emphasizing emergence as a dynamic change process. Our model should dampen policymaker enthusiasm for VC as a "silver bullet" in the entrepreneurship development process, suggests the importance of sequencing in the design of government programs supporting $\mathrm{VC}$ development, calls attention to the limits of engineering coproduction in stimulating $\mathrm{VC}$ emergence in emerging markets contexts, and highlights the importance of an economy's status as a limited access order in facilitating VC emergence. Fund managers and high-potential entrepreneurs can play a vital role in facilitating VC emergence through more careful pre-planning and the establishment of innovation associations.

Keywords: Venture capital; emergence; Africa 


\section{Toward a Process Model of Venture Capital Emergence: The Case of Botswana}

\section{INTRODUCTION}

This paper examines the process through which VC industries emerge in weak institutional environments, using Botswana as an exploratory case study and focusing on the role of diffusion. Process data from Botswana indicate that the diffusion of $\mathrm{VC}$ models and related institutions contribute to the $\mathrm{VC}$ emergence process. The diffusion process operates at the country, fund, and individual levels and arises at the intermediate stage of the multi-stage $\mathrm{VC}$ emergence process, when coproduction occurs between government investors seeking to fill the "equity gap" and private sector fund managers. Diffusion requires the establishment of simultaneity conditions and precedes the $\mathrm{VC}$ cycle, when $\mathrm{VC}$ funds raise capital and invest, monitor, and exit from seed, startup, and early stage investments prior to raising new funds.

$\mathrm{VC}$ is concerned with seed, startup, and early stage investing in firms involved with innovative products or processes. To date the bulk of VC activity has been confined to economies with strong institutions characterized by adequate protection of minority investor rights and liquid public equity markets. A literature has emerged on the relationship between institutional conditions and VC activity (e.g. Jeng and Wells, 2000), but the processes of VC emergence remain less well understood, in part because fund managers, investors, and governments can be reluctant to share the rich, granular data from which a process model of VC emergence can be developed. However, VC's role in supporting entrepreneurship development, innovation, and economic growth, as well as the light that research on the $\mathrm{VC}$ emergence process may shed on other examples of organizational and industry emergence, would seem to justify such an effort. 
To date, most VC research has taken a variance approach (Mohr, 1982; Van de Ven and Poole, 1995), with a few exceptions confined to corporate venturing (e.g. Burgelman, 1983; Garud and Van de Ven, 1992). Like many other social scientists, VC scholars also assume that "the societies they live in are the historical norm" (North, Wallis, and Weingast, 2009) and, by extension, that organizational phenomena studied in these setting are the norm, resulting in existing theories about $\mathrm{VC}$ and entrepreneurship derived almost exclusively from the experiences of advanced industrialized democracies. In fact, $85 \%$ of the world's population currently lives in societies governed by fundamentally different social orders that are characterized by slowgrowing and shock-prone economies, populations governed by states that lack generalized consent, small numbers of formal organizations, smaller and more centralized governments, and social relations dominated by personal connections (North, Wallis, and Weingast, 2009).

These variance studies of VC emergence (Manigart, 1994; Gompers and Lerner, 2000; Gilson, 2003) have identified many of the determinants of emergence, but a model describing how these elements and others interrelate has remained elusive. This paper follows Lingelbach, Murray, and Gilbert (2008) by offering a new, case study based approach to the development of the VC system in Botswana. This focus on the emergence of VC systems in an emerging market context allows for the development and refinement of the theory about how VC emerges. In particular, this work on the Botswana experience has identified the importance of diffusion as an additional element in explaining VC development.

As with most organizational categories, $\mathrm{VC}$ consists of a stable prototypical core, consisting of "certain generic rules containing a canonical image of the image of the activity to be carried out" 
(Tsoukas and Chia, 2002: 573). Radiating from this core is a more unstable, non-prototypical part, and it is in this portion of any category that change in the category is likely to arise (Tsoukas and Chia, 2002). To understand how VC has changed as an organizational form, it is important to study its unstable, marginal manifestations, which are often found in weak institutional environments.

The VC core organizational form is usually defined in the literature as "a professionally managed pool of capital that is invested in equity-linked securities of private ventures at various stages in their development" (Sahlman, 1990). VC organizations following this form typically finance the creation of new assets involving young firms often based on innovative technologies. This core concept of VC appears to have been pioneered in the United States beginning in 1946 (Gompers, 1994), although some evidence exists of simultaneous emergence in the United Kingdom (Coopey and Clarke, 1995).

While the delineation of VC's core is noncontroversial, the composition of VC's nonprototypical part is more interesting and challenging, as is the case with most organizational concepts. As VC has been introduced in different industry and geographical contexts, a variety of new $\mathrm{VC}$ forms have emerged, including corporate $\mathrm{VC}, \mathrm{VC}$ funds organized as corporations rather than limited partnerships, and government-managed funds. As a result, VC's boundaries have been continuously redefined as it has diffused into new contexts. The range of VC systems that have emerged internationally suggests that institutions play an important role in its development. A study of VC in one non-prototypical domain-Botswana-represents a potentially rich opportunity to tease out some of the ways in which VC has changed in response 
to institutional conditions. The core concept of $\mathrm{VC}$ pioneered in the American institutional context has generally required a strong set of institutions, evidenced by protection of minority investor rights and liquid equity markets. When those institutions are either weak or absent, as is the case in many developing countries, the core concept of $\mathrm{VC}$ must be altered if $\mathrm{VC}$ is to exist as an organizational form. How $\mathrm{VC}$ is altered and consequently emerges in weak institutional environments is a question of interest to researchers, policymakers, and practitioners (Lingelbach et al., 2008).

Weak institutional environments have been recently re-conceptualized as limited access orders (LAOs), which control access to the political and economic organizations that create economic rents and thus maintain order by co-opting a society's elites (North, Wallis, and Weingast, 2009). Three types of LAOs have been identified —-fragile, basic, and mature. Of these, VC in developing countries mainly emerges in mature LAOs (such as Botswana), in which large numbers of organizations exist outside the state, but are sanctioned by the state, resulting in limited competition and the maintenance of economic rents for the elites comprising a society's dominant coalition. Because the innovation financed by VC creates potential competition for the firms controlled by a mature LAO's elites, thus disrupting their economic rents, dominant coalitions in mature LAOs are likely to adopt technology selectively and may seek to actively disenable the organizational density required for indigenous technological innovation (North, Wallis, Webb, and Weingast, 2007). As a result, VC in these settings may tend to look fundamentally different from $\mathrm{VC}$ in open access orders, where political and economic competition results in the rapid erosion of political and economic rents. 
An earlier effort developed a preliminary theoretical model of the $\mathrm{VC}$ emergence process from South African data (Lingelbach et al., 2008). However, we question the generalizability of this model, given the idiosyncratic nature of the South African institutional framework (where VC has already emerged but now appears to be submerging). A second case study is required to validate this model's general structure, while modifying it to reflect new data from a different institutional setting that is broadly similar to that of South Africa, but where VC is either nascent or in the early stages of emergence. This second case study also allowed for the further development of the theoretical model advanced in Lingelbach et al. (2008). The importance of diffusion in the process of VC emergence becomes clear in this context.

Like South Africa, Botswana is an upper-middle income country of English legal origin in the African cultural cluster and with a natural resource-dependent economy. Botswana's postindependence history is one of the few success stories in sub-Saharan Africa, producing both high rates of growth and a relatively robust democracy (Leith, 2005; Acemoglu, Johnson and Robinson, 2001). However, Botswana's development trajectory has been significantly different from South Africa's, permitting variation that allows for validation and modification of the emergence model elaborated in Lingelbach et al. (2008).

\section{WHAT DO WE KNOW ABOUT HOW VENTURE CAPITAL EMERGES?}

An earlier paper introduced a new model of VC emergence (Lingelbach et al., 2008). Based on process data from South Africa, this model described a three stage process through which VC develops: 
Insert Figure 1 about here

This model incorporates two narratives of VC emergence that have been developed to date, while introducing a third process--coproduction. The first narrative calls attention to the need for the simultaneous presence of three macro-level factors - sufficient stocks of capital, specialized financial institutions, and entrepreneurs - in order for VC to emerge (Gilson, 2003) and properly notes the challenges of engineering these simultaneity conditions. A second narrative describes VC as a micro-level cycle consisting of five activities: fundraising, investing, monitoring, adding value, and exiting (Gompers and Lerner, 2000). Both of these narratives describe life cycle processes of social change (Van de Ven and Poole, 1995), which have as their essential characteristic a necessary, logical sequence of events.

The model depicted in Figure 1 links the narratives of Gilson (2003) and Gompers and Lerner (2000), while incorporating an intermediate process of coproduction between government investors and fund managers which is purposeful in nature. Coproduction describes a process in which inputs from individuals in different organizations are transformed into goods or services (Ostrom, 1996). Purposeful processes can be distinguished from life cycle ones by their goaloriented, adaptive natures. Purposeful processes are more entrepreneurial and opportunistic by nature. Coproducing VC between government investors and fund managers becomes essential to VC emergence in weak institutional environments, where the "equity gap" is particularly pronounced, as reflected in the South African experience in developing a VC industry (Lingelbach et al., 2008). 
The model strongly suggests that $\mathrm{VC}$ will not emerge organically in the presence of strong enabling conditions, but, instead, must be coaxed into life through cooperation between government investors and fund managers. This cooperation does not necessarily arise because these actors are driven to do so by rational economic self-interest. Instead, this cooperation must be broader and deeper in nature. However, what this model of the VC emergence process appears to have missed is the role played by diffusion, i.e. the impact of the growth of $\mathrm{VC}$ in other countries and within the country itself. We now explore this concept further, before developing an augmented model based on the experience in Botswana.

\section{The Role of Diffusion}

The global spread of VC can also be understood through the theoretical lens of diffusion. Diffusion is "the process by which an innovation is communicated through certain channels over time among the members of a social system" (Rogers, 2003: 35). North American diffusion theory is grounded in an epidemic (or learning) framework, which is based on the spread of agricultural innovations, educational innovations, and disease (Griliches, 1957; Mansfield, 1968; Rogers, 2003). Under this framework, diffusion happens when information spreads. In order for information to spread, the institutional environment must be conducive to both its spread and its adaptation in new host environments.

The North American diffusion school describes the innovation-diffusion process as a multi-stage process consisting of the innovation decision (comprised of five steps: knowledge, persuasion, 
decision, implementation, and confirmation), followed by either adoption or rejection. Adoption may be followed by later discontinuation of the innovation, while rejection can lead to later adoption (Rogers, 2003). Decisions to adopt an innovation can be made individually, collectively, or by authority figures (Rogers, 2003). A relatively neglected subfield within North American diffusion research is that which examines the rate of adoption of innovations in different social systems (e.g. Rogers and Kinkaid, 1981); this subfield is of direct relevance to developing a general model of $\mathrm{VC}$ emergence across different institutional environments. Rate of adoption is a function of "system norms, characteristics of the social system (such as concentration of opinion leadership), change agent variables (such as their strategies of change), and types of innovation decisions" (Rogers, 2003: 97). The characterization in the literature of the diffusion process as multi-stage strongly suggests that this process is life cycle in nature, as are the simultaneity and VC cycle components of the current emergence model.

The North American diffusion of innovation literature makes two assumptions: 1) innovations change little as they diffuse from one site to another, and 2) adopters adopt innovations for the same reasons (Abrahamson, 2006). These assumptions have been challenged by other research arguing that: 1) adopters translate innovations in ways that change both the imitator and the imitated; and 2) adopters translate innovations to suit their idiosyncratic circumstances (Czarniawska and Sevón, 2005; Abrahamson, 2006). To the extent that translation enters into the diffusion process, the stage process theory of diffusion has to be modified to incorporate other processes, which might be evolutionary, dialectical, or teleological in nature. 
Endemic innovations are those that are exclusively native to an organizational population, such as a national VC industry (Gaba and Meyer, 2008). Innovations can spread to other populations or be rejected at the border of the organization's population. Barriers to the spread of endemic innovations across organizational populations can include institutional norms, industry standards, technology platforms, regulatory regimes, and cultural practices (Gaba and Meyer, 2008), all of which tend to change slowly. In some cases, endemic innovations adapt in order to successfully cross borders into new organizational populations. Examples of such adaptation include the transformation of the software industry's open source model to biotechnology, industrial design, and NASA's Mars mission (Goetz, 2003); the changes made to Japanese lean production methods by other industries in other countries (Womack, Jones, and Roos, 1990); and the morphing of microfinance (originally conceived by non-governmental organizations in developing countries) into the commercial lending sector (Armendariz de Aghion and Morduch, 2005).

A recent model of cross- and intra-population diffusion of endemic innovations using data from U.S. corporate venture capital (CVC) programs in the information technology (IT) industry (Gaba and Meyer, 2008) predicts that 1) geographical proximity to a VC population cluster increases the probability of CVC program adoption by an IT firm and 2) the likelihood of CVC program adoption is positively related to the efficacy of investments made by the $\mathrm{VC}$ population. These findings suggest that the $\mathrm{VC}$ diffusion process is rational and largely evolutionary in nature. While the findings of Gaba and Meyer (2008) are based on the diffusion of innovation between different organizational populations, diffusion among other population types formed by shared language, values, or nationality may have different characteristics, 
posing the question: is it more difficult to "take VC to IT or to Asia?" (Gaba and Meyer, 2008: 995).

Copying organizational forms across national boundaries can be dangerous for entrepreneurs (such as those that are involved with the establishment of national VC industries). Selection forces determining which organizational forms will survive may be present in one setting but not in another, and differing institutional structures may reduce or eliminate the advantages of routines and competencies as they move from one population to another (Aldrich and Ruef, 2006). For example, the first movers in the Swedish VC sector initially copied business models from Silicon Valley. After imitators failed, they adapted new approaches better suited to the Swedish institutional environment (Aldrich and Ruef, 2006).

\section{Propositions}

Based on this literature review, we suggest that $\mathrm{VC}$ is an innovation that may be spread to weak institutional environments through a multi-stage process that is shaped by decisions made by fund managers, government investors, and investees made in social systems with varying characteristics (Rogers and Kinkaid, 1981; Rogers, 2003). Evidence from U.S. corporate venture capital activity provides empirical support for the diffusion of $\mathrm{VC}$ activity across organizational populations with differing characteristics (Gaba and Meyer, 2008). Specifically, we suggest that:

Proposition 1: Diffusion of VC models from other institutional environments plays a significant role in the $V C$ emergence process. 
Given that innovation adopters may translate innovations (Czarniawska and Sevon, 2005; Abrahamson, 2006), and that adopters may translate in response to institutional conditions that are different from those in the organizational population originating the innovation, we suggest that predecessor conditions, such as those described in Gilson (2003), may shape the way that VC models are diffused. Therefore, those conditions may logically precede the diffusion process itself. Diffusion requires agents acting to adopt innovations, and, in the instance of VC model diffusion, we suggest that those agents are both VC fund managers and government investors in VC funds, both of which seek to create a sufficient level of VC activity to meet their individual and collective goals. Diffusion of VC models provides the 'irritant in the oyster' needed to catalyze coproduction between fund managers and government investors. Specifically, we suggest that:

Proposition 2: VC model diffusion logically follows the establishment of simultaneity conditions, is coterminous with coproduction, and precedes the VC cycle in the emergence process.

Gaba and Meyer (2008) demonstrate that geographical proximity of efficacious VC industry increases the likelihood of $\mathrm{VC}$ model adoption by an organizational population. Therefore, we suggest that:

Proposition 3: VC model adoption is facilitated by geographical proximity of active VC industries in other economies. 


\section{RESEARCH METHODOLOGY}

As with earlier process studies involving long-term time horizons (Burgelman, 1983), a qualitative method using a longitudinal-processual approach (Pettigrew 1979) was used to study VC emergence comprehensively in one setting. An earlier theoretical model inductively derived from exploratory case studies at the program (Lingelbach et al., 2008) and fund (Lingelbach and Sherwin, 2008) levels formed the basis for data collection, with the recognition that this model was incomplete due to the incomplete documentation of the $\mathrm{VC}$ emergence phenomenon.

The choice of Botswana as a case setting was governed by a variety of factors. The selection of cases in case study-based research must be logically linked to the research propositions being explored (Yin, 2003). Given the propositions elaborated above, a case setting where VC model diffusion may be present, and where possible coproduction between government investors and fund managers may be involved, seems most appropriate. The choice of a case involving a VC industry in an economy where $\mathrm{VC}$ is least well-established also seems promising as a means to observe the emergence of organizational change (Tsoukas and Chia, 2002). Since the literature suggests that $\mathrm{VC}$ industries are more likely to emerge in English legal origin countries, due to the greater likelihood of minority investor rights protection (La Porta, Lopez-de-Silanes, Shleifer, and Vishny, 1998), a case drawn from such a setting offers a greater likelihood of observing VC emergence than one drawn from other legal origins. Finally, this paper follows earlier papers on South African VC emergence (Lingelbach et al., 2008; Lingelbach and Sherwin, 2008), and the comparison to South Africa — where an emerged VC industry was observed — suggests that, given the complexity of the $\mathrm{VC}$ phenomenon, a comparative case that controls for as many other variables as possible should be selected. 
Each of these factors led us to select Botswana as a case subject from a total estimated population of 37 national venture capital industries in developing countries ${ }^{1}$ Initial evidence $^{-1}$ indicated that Botswana may have diffused VC models from other populations, the VC industry appeared to be nascent or in the early stages of emergence (no national VC association exists), and the country is classified as English legal origin. ${ }^{2}$ The choice of Botswana also allows this study to control for GDP/capita in comparison to the earlier South African studies (both countries are classified as upper-middle income by the World Bank) and geographical endowment, which is correlated with colonial settler mortality and, through this mechanism, the quality of institutional endowments (Acemoglu, Johnson, and Robinson, 2001, 2002, 2003). One possible criticism of the choice of Botswana as a case study is that it is too limited - the industry is small, has not completed a full cycle of investing and exiting, and is almost entirely financed by the national government. Our hope is that, by studying an industry that is in the process of emergence, insights may be gained that are not available by studying already-emerged industries.

This paper takes a weak process research approach (Rescher, 1996; Chia and Langley, 2004; Tsoukas, 2005; Van de Ven and Poole, 2005), which has been successfully implemented in

\footnotetext{
${ }^{1}$ This population consists of 14 countries of English legal origin with nascent or emerging venture capital industries (Bangladesh, Botswana, Ghana, Jamaica, Kenya, Namibia, Nigeria, Pakistan, Samoa, Sri Lanka, Tanzania, Trinidad \& Tobago, Vanuatu, and Zambia), 4 English legal origin countries with emerged VC industries (India, Malaysia, South Africa, and Thailand), 13 French legal origin economies with nascent or emerging VC industries (Argentina, Bolivia, Chile, Colombia, Costa Rica, El Salvador, Jordan, Madagascar, Mauritius, Morocco, Oman, Peru, and Senegal), and 6 French legal origin countries with emerged industries (Brazil, Indonesia, Mexico, Philippines, Tunisia, and Turkey). Although other legal origin types exist (German, Scandinavian, and socialist), English and French legal origin account for 121 of the 152 countries classified as low- or middle-income by the World Bank. While no agreed methodology for determining the existence of an active VC industry exists, one possible measure is the presence of a national venture capital association (Kenney, Haemmig, and Goe, 2006).

${ }^{2}$ To be more precise, Botswana is classified in the comparative law literature as a mixed legal system containing elements of both common and civil law. Other countries or sub-national entities with mixed legal systems include South Africa, Zimbabwe, Namibia, Lesotho, Swaziland, Sri Lanka, Scotland, Quebec, and Louisiana. Like South Africa, Botswana is considered to be a mixed system based on English common law (Zimmermann and Visser, 1996).
} 
qualitative studies of organizational change (e.g. Mintzberg, Raisinghani, and Theoret, 1976;

Leonard-Barton, 1990). While the phenomenon under study (VC emergence) is not fully understood, and therefore generally more amenable to study using strong process research methods (Tsoukas, 2005; Poole, 2008; Edmondson and McManus, 2007), and while the authors generally hold a processual ontology consistent with either strong process research or variance studies of organizing (Van de Ven and Poole, 2005), our inductive approach to theory-building led to a phasic model of VC emergence (Lingelbach et al., 2008) more consistent with weak process research.

Methodologically sound case studies place primary emphasis on providing primary and secondary reports on reliability, construct and internal validity (Gibbert, Ruigrok, and Wicki, 2008). Methodological rigor was maintained in this study as follows. With respect to reliability, the interviewer usually began with an invitation to tell about origins of interest in $\mathrm{VC}$, then directed discussion toward four questions: 1) how did VC in Botswana come about?, 2) how would you evaluate the role of government in VC?, 3) how can the level of entrepreneurship in Botswana be characterized, and 4) how can the level of innovation in Botswana be described? Respondents were asked to link their statements to those made by other respondents and to provide specific examples where possible. Semi-structured interviews were conducted in person by both co-authors in Gaborone, Botswana in June and October 2008. As noted, where possible these interviews were recorded and transcripts prepared from audio recordings, while in other instances detailed notes were taken and transcribed after the interview to minimize misunderstanding. Archival research was based on internal documents provided by Venture 
Partners Botswana (VPB), as well as a review of newspaper articles available in the online archives of Mmegi, Botswana's principal independent newspaper.

Construct validity is obtained by using data from two sources - interviews with government officials and fund managers in Botswana, and archival material from multiple sources. These data were gathered by both authors and a clear chain of evidence maintained. Data from a third source, such as direct observation, was not available and judged to be relatively unimportant. Data was collected through direct contact with fund managers and an introduction to government officials provided by one author's contacts in Botswana's financial sector. While access to fund managers was readily obtained, access to government officials proved more difficult than expected, and interviews were conducted with lower level officials than would have been optimal. Once data was collected, coding was conducted, based on a system developed for Lingelbach et al. (2008), and events were identified, from which a narrative was constructed. Construct validity has been weakened by the absence of peer and informant review of transcripts.

Internal validity has been developed by direct reference to the earlier literature on $\mathrm{VC}$ emergence and diffusion, while external validity was established by using a process model developed from Lingelbach et al. (2008) and using a nested approach: examining data from Botswana at both the program and fund level. The rationale for the selection of Botswana, as well as the context within which its VC industry has emerged, is described later in this paper. 


\section{BOTSWANA: THE CONTEXT FOR VENTURE CAPITAL EMERGENCE}

Extremes characterize the environment in which Botswana's VC industry has emerged. The darling of mystery writers, development economists, and Western eco-tourists, Botswana also has the highest incidence of HIV in its adult population of any country in the world and may largely revert to uninhabitable desert in a warming world. These extremes contribute to high levels of uncertainty in a business environment mediated by a democracy rooted in a tribal politics of consensus (Leith, 2005; Acemoglu, Johnson and Robinson, 2001). Despite the underlying uncertainties of its environment, Botswana's post-independence history has been characterized by some researchers as one of the few development success stories in sub-Saharan Africa, producing both high rates of economic growth over several decades and a relatively strong democracy rooted in a tribal politics of consensus (Leith, 2005; Acemoglu, Johnson, and Robinson, 2001; Thumberg-Hartland, 1978; Samatar, 1999; Picard, 1987; Werbner, 2004) that has been able to escape the resource curse (Beaulier and Subrick, 2006). Prudent management of diamond-related revenues through a careful balance between fiscal and monetary prudence and provision of public goods and social welfare has been a principal contributor to this perceived success (Clover, 2003). Other scholars has pointed out the corruption associated with economic development in Botswana (Good, 1992, 1994, 2002), the country's 'authoritarian liberalism' and absence of elite accountability (Good, 1996; Good and Taylor, 2005; Swatuk, 1998), the active racism practiced against the San minority by the Botswana government (Good, 1993), and restrictions on academic freedom (Taylor, 2006). These contradictory findings have led some observers to refer to Botswana as a paradox (Clover, 2003), although these conditions are 
precisely those found in one form or another in most other limited access orders (North, Wallis, and Weingast, 2009). These conditions shape the emergence of both new ventures and VC.

Botswana's development trajectory has been significantly different than neighboring South Africa's. Like Lesotho, Swaziland, and, to a lesser extent, Namibia, Botswana has been dependent on South Africa for much of its economic history up to and through independence from Great Britain in 1966 (Mhone and Bond, 2001). Exports of migrant labor to South Africa (as well as beef exports to Europe), imports of finished goods from South Africa, and a common monetary policy with South Africa characterized the economy in Botswana during the pre- and early post-independence years. Botswana has a shared dependence (with South Africa) on the extraction and export of minerals. It is the largest supplier of diamonds in the world by value. Mining activities accounted for $39 \%$ of the country's GDP in 2007/2008, with exports of diamonds alone accounting for $25 \%$ of GDP during this period (Bank of Botswana, 2008).

The total factor productivity of firms in Botswana is approximately $1 / 2$ of those in South Africa, indicating a relative lack of competitiveness (World Bank, 2007a). Few manufacturers in Botswana are exporters, and local sales are concentrated with government buyers (World Bank, 2007a). An emphasis on diamond mining, the economy's small population, and Botswana's geographical remoteness may all play a role in firm competitiveness (World Bank, 2007a), constraining the opportunity set available to entrepreneurs and fund managers.

The emergence of VC in Botswana has taken a much different path than in South Africa, with the nature of Gilson's simultaneity conditions - sufficient stocks of entrepreneurs, pools of 
capital dedicated to $\mathrm{VC}$ investment, and specialized financial institutions - shaping the opportunity set available to fund managers. Given the much smaller size of the local economy, the overall stock of entrepreneurs (as represented by the number of new corporations formed each year) is much lower than in South Africa. Yet, measured as the percentage of new corporations to total corporations, Botswana's rate of new firm formation (11.2\%) was significantly higher than South Africa's (6.4\%) over the period 2002-5 (World Bank, 2008). Botswana's entrepreneurial landscape has been shaped by its tribal structure, in particular the predominance of minority Kalangese in the country's initial entrepreneurial stock, and their sometimes-contentious relationship with the majority Tswana (Werbner, 2002).

While Botswana's new firm formation rate is relatively robust, the country's industrial structure is less oriented to technology-oriented industries than South Africa's, limiting the deal flow of high growth seed, startup, and early stage firms needed to achieve VC's desired internal rates of return (IRRs). The World Economic Forum's 2007-8 Networked Readiness Index is one proxy measure of a country's technology stock and ranks Botswana $78^{\text {th }}$ of 127 countries, compared to South Africa, which is ranked $51^{\text {st }}$ (World Economic Forum, 2008).

Gilson's second simultaneity condition—sufficient pools of capital—is more challenging to assess. Botswana's pension fund sector has grown rapidly in recently years and total assets under management equaled Pula 29.01 billion at 12/31/06, up 25\% from 12/31/05 (African Development Bank, 2006). ${ }^{3}$ However, despite a $67 \%$ allocation to equities, the majority of pension fund assets in Botswana are invested offshore. Local private equity (PE) and VC has only been recognized recently by some local pension fund managers as a possible investable

\footnotetext{
${ }^{3}$ The Botswana Pula exchange rate was Pula 7.51/USD and 10.33/Euro on January $6^{\text {th }}, 2009$.
} 
asset class, and, of those few funds which have invested in local PE funds, the emphasis, as elsewhere, has been principally on later stage transactions. Angel investor interest in seed, startup, and early stage finance appears to be virtually non-existent. Thus, a Botswana "equity gap" appears to exist.

Gilson's third simultaneity condition is the existence of specialized financial institutions capable of conducting VC. Botswana's legal and regulatory environment does not appear to impede the establishment of VC funds, as evidenced by the ease with which VPB established its first fund in the country. However, VPB's second fund will be denominated in Euros, domiciled in Mauritius, and has a regional investment strategy (Venture Partners Botswana, 2008), suggesting that international institutional investors may prefer a domicile other than Botswana.

We conclude that Botswana's simultaneity conditions - the essential enabling conditions for VC emergence - are slightly inferior to those of South Africa, suggesting that the industry may face greater challenges in establishing itself, all other factors being equal. Yet, as we will see, despite these weaker simultaneity conditions, the VC industry in Botswana has developed more rapidly than in South Africa, suggesting that other factors in the emergence process may be playing a role.

\section{VENTURE CAPITAL IN BOTSWANA: A HISTORY}

The history of VC in Botswana generally follows the pattern of emergence described by Lingelbach et al. (2008), while also demonstrating the role of diffusion in this process. In 
comparison to South Africa, slightly weaker simultaneity conditions are offset by both stronger coproduction and robust diffusion from South Africa, a geographically proximate population, to create a smoothly functioning VC cycle evidenced by exits and the successful raising of one second fund.

With a much smaller economy than neighboring South Africa, it is not surprising that Botswana's PE and VC sector is significantly smaller as measured by the number of funds operating at present or funds under management. However, when funds under management are compared to GDP, Botswana's sector compares favorably to other countries, as the following chart indicates:

Insert Figure 3 about here

The history of VC in Botswana can be divided into three periods: antecedents (1966-1997), first efforts (1997-2002), and steady emergence (2002-present). The following timeline indicates some of the key milestones in VC emergence in the country:

Insert Figure 4 about here

\section{Antecedents (1966-1997)}

Botswana's economy was characterized at independence as one driven by agriculture, primarily cattle herding. The government's efforts from inception were directed in part in diversifying 
away from agriculture and, later, mining through industrialization, although these efforts only partially succeeded. In addition, the government also encouraged both citizen economic empowerment and private enterprise development (Leith, 2005). These broader developmental goals helped to shape the goals of VC development in the country.

From independence the diffusion of ideas and practices from around the world was facilitated by Botswana's extensive reliance on foreign technical assistance personnel on long-term assignments from the United Kingdom and other donors (Leith, 2005). Botswana's first president, Seretse Khama, signaled the government's commitment to the maintenance of this transmission mechanism when he said that "we should never sacrifice efficiency on the altar of localization" (Fawcus and Tilbury, 2000: 218). Many of these foreign advisers were more interested in adapting best practices to local conditions, rather than taking standard approaches or advocating their donor agency's agenda (Leith, 2005), creating an unusual institutional capacity in support of locally sensitive diffusion. The extensive use of foreign technical advisers in postindependence Botswana may reflect colonial-era usage of foreign missionaries by the Tswana tribes as a check on the influence of other whites in then-Bechuanaland.

Two early instruments of industrialization policy were the National Development Bank (NDB), which was established in 1965, and the Botswana Development Corporation (BDC), which commenced operations in 1970. As with many other development banks, NDB lent funds to sectors that the small local commercial banking sector was reluctant to finance. NDB faced a number of scandals that resulted in its near bankruptcy in late 1993. These scandals included a large portfolio of bad loans, which included large exposures to senior government officials and 
ministers (including then-President Masire). Entrepreneurship and VC (and government assistance to these activities) suffered a black eye when Masire attempted to justify NDB's loans to various officials by noting that Botswana was "a highly risky area" where "people who venture" were "the hope of our society" (Good, 1994).

Two incentive programs were established during the 1980s - the Financial Assistance Policy (FAP, established 1982) and Selebi-Phikwe Regional Development Project (SPRDP, established late 1980s). These programs failed in their objectives to create employment in non-traditional sectors, due to lack of monitoring and poorly designed incentive structures. SPRDP was absorbed into FAP in the mid-1990s, and FAP was replaced by the Citizens Entrepreneurial Development Agency (CEDA) in 2001 (see below). By the mid-1990s, a legacy of failure and, in some instances, fraud hung over government attempts to diversify the economy in Botswana.

FAP was the more important of the two incentive programs. It provided grants to both citizens and foreigners in Botswana for both equipment and labor and focused on the manufacturing sector. FAP was administered by the Ministry of Finance, while NDB disbursed funds for the program. Prospective grantees applied at local FAP offices and their applications were reviewed by a committee consisting of Ministry of Finance and Ministry of Commerce and Industry officials. The latter ministry processed approved applications and arranged monitoring and training, while the Local Enterprise Agency (LEA) provided mentoring. Some effort was made to develop a local textile industry, but current government officials could point to only one "success story" from the FAP effort—Caratex. 
According to current government officials, FAP was plagued by a lack of training for the entrepreneurs who were to have benefited from its financing. Many businesspeople did not know how to run their own businesses, and FAP did not provide sufficient monitoring or insist of the establishment of accounting standards for firms established with FAP funds.

\section{First Efforts (1997-2002)}

The first attempt at creating a PE or VC fund in Botswana was Peo Venture Capital, established in 1997. Peo is a joint venture between Debswana (itself a 50/50 joint venture between the government in Botswana and De Beers) and De Beers Botswana. The stated objective of Peo is "promoting and facilitating the establishment of commercially viable enterprises in Botswana as well as promoting the involvement of Batswana as owners in these in business (sic)." (Debswana, 2009). Peo has invested Pula 29.2 million in 54 businesses as of August 2007 (Ministry of Trade and Industry 2007). These investees have created 1091 jobs. Peo has invested primarily in already-profitable businesses, strongly suggesting that it has focused on small and medium-sized enterprise (SME) finance and, perhaps, PE as opposed to VC.

The establishment of CEDA in 2001 marked an important milestone in entrepreneurship and VC development in Botswana. CEDA was modeled on South Africa's black economic empowerment initiative (which had been under discussion since the early post-apartheid era), indicating another channel through which institutions shaping $\mathrm{VC}$ emergence diffused to Botswana. According to one government respondent, CEDA's purpose was to improve the country's base of entrepreneurs through subsidized loans, which was felt to be a structural 
improvement over FAP's grants. In addition, unlike FAP, CEDA was able to look at any firm that made commercial sense, although as a practical matter industry focus under CEDA appears to have shifted to agribusiness and franchising. An increased emphasis on mentoring and training, including enhanced informal reporting to mentors, was also an important component of CEDA's initial programs. Despite these changes, CEDA still encountered many problems, including high levels of loan default, continued diversion of funds and unrealistic expectations, often reflected in overspending, by entrepreneurs in the program.

While CEDA's initial efforts were focused on debt financing of small, locally owned enterprises, the government in Botswana provided for the agency to invest equity in larger firms, potentially owned in part by foreigners. As a result of a 2001 study by a consultant from the Development Bank of Southern Africa (DBSA), a decision was made to outsource equity investment to an independent firm, which provided the basis for the establishment of VPB's first VC fund.

However, government respondents recognized that, despite these program-level changes, the largest barrier to opportunity-oriented entrepreneurship in Botswana may be the attitude of citizens in Botswana to business, including the lack of complete commitment by owners and managers to their firms and the lack of expertise of many entrepreneurs in their firm's industry. Moreover, government respondents stated that the previous generosity of the government may have created a culture of nonpayment that limited VC efficacy. In comparison with South Africa, where government support for entrepreneurship and VC has been more limited, government respondents now believe that the government in Botswana may have provided too much support to these activities. 


\section{Steady Emergence (2002-present)}

The single most significant player in Botswana's VC industry has been VPB. VPB's first VC fund was established in 2002 with a Pula 200 million investment from CEDA. One respondent indicated that a combination of supply and demand pressures led to this fund's founding. At that time, the government in Botswana faced four related challenges: it was liquid with excess cash from diamond exports, demand was increasing for increased citizen participation in the economy, the country's SMEs were demanding new sources of funding, and the need remained to diversify of the economy beyond mining and agriculture. ${ }^{4}$ The country's pension funds were unable to find sufficient local investments beyond the government's bonds and the small local equity market. At the same time, local entrepreneurship was foundering. According to this respondent, only 30,000 citizens in Botswana were involved with a formal business (no more than $10 \%$ of the total labor force), of which approximately 6000 were employed in businesses that trade continuously. The economy in Botswana was full of what Anthony Siwawa, VPB's founder and CEO, called "one dimensional businesses," such as bed and breakfasts (B\&Bs), as opposed to two dimensional businesses that would, for example, provide services to B\&Bs. The principal national university, the University of Botswana, graduated only 5-10 business students each year, further limiting the pool of human talent from which entrepreneurship might emerge. Siwawa reflects the multiple channels through which VC diffused into Botswana from South Africa and the United States. Prior to returning to his home country, Siwawa worked for Deloitte Touche in South Africa, where he was involved with establishment of a $€ 100$ million regional PE fund. He subsequently joined this fund and assisted in the conclusion of transactions

\footnotetext{
${ }^{4}$ One VC fund manager said that "the country needed equity finance."
} 
in Angola, Namibia, Zambia, and Zimbabwe. He is also in process of obtaining a MBA from University of Chicago and began his career at Debswana, De Beer's subsidiary in Botswana.

VPB was created as one of the first outsourcing initiatives of the government in Botswana. A Zimbabwean consultant from DBSA was hired by the government via the African Management Services Company (AMSCO), an organization founded by the United Nations Development Program (UNDP) and the International Finance Corporation (IFC); his final report recommended outsourcing in light of the many failed government programs, e.g. FAP and NDB. This is the first concrete example of diffusion of the VC model, as a senior executive at DBSA at that time played a central role in the establishment of South African VC industry in her previous position as head of VC at that country's Industrial Development Corporation (IDC). IDC was one of the earliest investors in South Africa's VC industry (Lingelbach et al., 2008).

Given the relative paucity of entrepreneurship in Botswana, the investment strategy of VPB has emphasized a generalist approach encompassing both early and later stage investments across a variety of sectors. Sixteen investments have been completed to date, of which $50 \%$ can be characterized as early stage. None of VPB's early stage investments appear to have been in innovative technologies or processes. Instead, most were in industries being replicated in Botswana for the first time. VPB has received regular requests for funding from South African early stage investees, indicating another channel for VC diffusion. While no exits from VC investments in Botswana have occurred via initial public offerings to date, the liquidity of the Botswana Stock Exchange (BSE) has been increased by the numerous listings on the BSE by either South African firms or local firms started in Botswana by foreigners. These listings 
contribute to the diffusion of institutions required for the successful operation of the $\mathrm{VC}$ cycle. Two of VPB's current investees are being prepared for initial public offerings (IPOs) on the BSE.

VPB has faced limited local competition for deals, although the development of a Botswana Innovation Hub (including an incubator and early stage technology fund) may provide alternative sources of VC funding in the country. The Innovation Hub's business plan was prepared by Technopolis, a Finnish science park operator. According to one respondent, two foreign PE and VC funds-DBSA from South Africa and Tuninvest from Tunisia- have visited Botswana in search of transactions, but have not completed any investments to date.

VPB is now in the process of raising a $€ 120$ million regional fund and has secured funding commitments from investors that have invested in $\mathrm{VC}$ funds in other developing countries, including the International Finance Corporation (IFC), Netherlands Development Finance Company (FMO), and Commonwealth Development Corporation (CDC). These investors provide an important new channel for the diffusion of $\mathrm{VC}$ governance and monitoring practices.

A new channel for VC diffusion opened in March 2008, when the African Venture Capital Association (AVCA) held its $7^{\text {th }}$ annual conference in Gaborone. AVCA is an industry association with a goal of "promote, develop, and stimulate private equity and venture capital in Africa.;" total membership is 124 at present (AVCA, 2009). Established in 2001, AVCA was first headquartered in Cameroon but is currently based in South Africa. VPB (a member of both AVCA and the South African Private Equity and Venture Capital Association) acted as the 
co-host of the Botswana conference, which was sponsored by FMO. This event was attended by AVCA members from across Africa, as well as institutional investors and development finance institutions. Siwawa was subsequently appointed to AVCA's board of directors.

\section{Evaluating the Venture Capital Emergence Process in Botswana-The Role of Diffusion}

Diffusion of VC models and related institutions played a significant role in Botswana's VC emergence process at a variety of levels:

- At the country and program levels, a DBSA consultant completed the study establishing CEDA's VC program, the liquidity of the Botswana Stock Exchange is largely maintained by foreign listings, South Africa's BEE program served as the model for Botswana's citizens economic empowerment initiatives, and AVCA's 2008 conference forged new linkages between the VC industry in Botswana and fund managers and investors elsewhere.

- At the fund level, South African early stage firms sought funding from VPB's first fund, three development finance institutions have committed to invest in VPB's second fund, Peo Capital was set up by De Beers, two foreign PE investors have visited Botswana in search of deals, and the new Innovation Fund is being designed with foreign assistance.

- At the individual actor level, VPB's CEO gained PE experience in South Africa and is earning a MBA from an American university, and foreign technical advisers have played a long and major role in shaping economic policy in Botswana.

In the case of Botswana, the diffusion of the American VC model has been mediated largely through South Africa, resulting in two stages of adaptation and differing characteristics along 
several dimensions at each stage. Botswana represents an example of a second order nonprototypical case of the VC concept, with South Africa being a first order case:

\section{Insert Table 1 about here}

This evidence suggests that the diffusion of $\mathrm{VC}$ and related institutions to Botswana was largely a teleological process, driven by the government in Botswana and its development goals. Deliberate government actions at the country and individual actor levels facilitated diffusion of VC models and related institutions. Of these, the use of a DBSA consultant to design CEDA's VC outsourcing and the strong reliance on foreign technical advisers since independence played the most significant roles. In addition, evolutionary processes (typical of market-based competition) can be seen as contributing to the VC emergence process, of which Siwawa's South African experience, foreign listings on the local stock exchange, and Peo Capital's establishment by De Beers are the most important.

Diffusion has played an important role in the VC emergence process in Botswana. The government in Botswana and the country's most prominent $\mathrm{VC}$ firm drew on the experiences of South Africa, the United States, and elsewhere in their design of VPB, which broadly reflects international best practices. The relatively late establishment of VPB (especially given the level of economic development in Botswana) allowed adaptation of VC models to the country's unique conditions, resulting in a $\mathrm{VC}$ industry that is significantly more diversified a the fund level than in neighboring South Africa and (to date) entirely government-financed. An important limitation of Botswana's adaptation of the VC process has been a paucity of investment in 
innovative enterprises at the seed, startup, and early stages. The recent development of a government-funded Innovation Fund may be a start in addressing this gap.

\section{A MORE COMPLETE MODEL OF VENTURE CAPITAL EMERGENCE}

We find strong evidence to support each of our three propositions about the role of diffusion in the VC emergence process. Diffusion of VC models and related institutions from South Africa does appear to have played a significant role in the emergence of VC in Botswana. These influences took place at three levels — country, fund, and individual — and appear to have reinforced one another. In terms of sequence, diffusion appears to follow the presence of simultaneity conditions, which create the initial demand for VC, and to precede the VC cycle itself, which presumes some operational model of $\mathrm{VC}$ investing (whether purely indigenous or imported). The temporal relationship between diffusion and coproduction is more difficult to determine, but in Botswana's case the two processes appear to operate more or less simultaneously. The proximity of the emerged VC industry in South Africa contributed directly to Botswana's emergence; the earliest evidence of VC in Botswana (1997) occurred at least five years after South Africa's industry gained momentum.

Botswana's experience suggests that the existing model of VC emergence is incomplete. Specifically, the diffusion of VC models from other economies (in particular, South Africa) appears to have played an important intermediate role in the emergence process. In this case diffusion appears to enter the $\mathrm{VC}$ emergence process when government and private fund managers work to coproduce the industry. The close cooperation between VPB and the 
government in Botswana in this coproduction process is noted in the willingness of VPB to pursue non-profit maximizing goals, such as job creation, as part of its operation of the $\mathrm{VC}$ cycle. ${ }^{5}$ A variety of diffusion processes provides the conceptual yeast that stimulates coproduction, in part by helping to anchor discussion between the key stakeholders around possible solutions.

In this more complete model, simultaneity conditions set the scene for VC emergence. Sufficient stocks of opportunity-oriented entrepreneurs, capital demanding the risk-return profile of $\mathrm{VC}$, and specialized financial institutions able to manage the unique instrumentalities of $\mathrm{VC}$ create interest in and demand for $\mathrm{VC}$ as a product and, perhaps, as an industry. But the poor economic characteristics of seed, startup, and early stage investments, as well as the lack of attractiveness of angel investing as a substitute for $\mathrm{VC}$ in weak institutional environments characterized by lower levels of trust, poor tax administration, and higher levels ethno-linguistic fractionalization, lead to a need for pooled investment vehicles supported by the government to address the equity gap. At this point, diffusion of $\mathrm{VC}$ models from other environments becomes relevant.

Yet the South African experience suggest that government support for VC cannot "take off" unless government and private $\mathrm{VC}$ fund managers have common interests transcending profit maximization or financial sustainability (Lingelbach et al., 2008). The relatively high levels of trust between the government and the private sector in Botswana contributed to a quicker takeoff of VC in the country in comparison to South Africa. The task of VC industry development in weak institutional environments requires a "double bottom line" approach and a much higher degree of cooperation than a contractual, commercial, arms length relationship typical of limited

\footnotetext{
${ }^{5}$ One respondent indicated that "Botswana is a higher trust society than South Africa."
} 
partners' relationships with general partners in VC funds in developed economies. VPB refers to this "double bottom line" strategy in its public presentations. The intermediate role of coproduction in VC emergence is supported in the Botswana case.

Coproduction is facilitated by the diffusion (and proper adaptation) of VC models from elsewhere. With sufficient cooperation and adequate diffusion, fund managers and government can coproduce a sufficient number of success stories to cause the VC cycle to begin to operate on its own, without further government support. This process is unlikely to be linear-from simultaneity to coproduction and diffusion to the VC cycle. In particular, coproduction may have meaningful feedback effects on simultaneity, altering the stock of opportunity-oriented entrepreneurs and the risk-return calculations of potential VC investors. In turn, simultaneity conditions may shape coproduction and diffusion processes, in particular the necessity of government and fund managers to work with one another and the ways in which diffusion is adapted to a particular VC environment. These interrelationships can be indicated as follows:

Insert Figure 4 about here

\section{CONCLUSION}

While the proposed model of VC emergence must be validated in French legal origin economies, where institutional conditions are likely to vary significantly from those found in English legal 
origin countries, it provides a robust framework from which to assess implications for policymakers and development finance officials seeking to catalyze VC development. In particular, the complexity of this process should dampen policymaker enthusiasm for $\mathrm{VC}$ as a "silver bullet" in the entrepreneurship development process. A second policy implication evident from the experience in Botswana is that timing matters a great deal. As the literature on first mover advantage demonstrates, followers in new industries often perform better than leaders. A third policy implication may be that there are limits to engineering coproduction. Botswana's high level of trust between the public and private sectors was not created overnight and reflects a decades-long process of tribal integration. An inherent contradiction seems to exist between such high trust environments, often characterized by low levels of ethno-linguistic fractionalization, and the literature on ethnic entrepreneurship, which demonstrates the dynamism of ethnic minorities, including in weak institutional environments.

The complexity inherent in this study's model of VC emergence suggests the need for fund managers to undertake careful due diligence on the status of each sub-process before starting fundraising. In particular, fund managers must assess with a clear eye the likelihood that they can form a cooperative relationship with the relevant policy implementing agencies. For those fund managers with a regional or global asset allocation, the model argues for early monitoring of each of the antecedent sub-processes to the VC cycle, as it is the operation of these subprocesses that seem to largely determine whether the $\mathrm{VC}$ cycle will itself operate. Using existing datasets, it seems quite possible to monitor continuously the status of each of the antecedent subprocesses (simultaneity, coproduction, and diffusion) and thus more carefully plan a fund manager's entry point into a market for venture capital at the right time. Patience and discipline 
(two hallmarks of successful fund managers) are likely to be reinforced as a result of this monitoring.

High-potential entrepreneurs in limited access orders may find in this study's model an interest in forming 'innovation associations' to influence dominant elite coalitions toward the doorstep conditions needed for innovation-oriented open access orders. Such associations could complement existing national systems of innovation (usually government-led) and play a role in ensuring the efficient operation of coproduction between the public and private sectors in pursuit of active VC industries. Such associations could encourage the formation of more highpotential, high-growth new firms by emphasizing the fundamentally different determinants of such entrepreneurship in comparison to that focused on either necessity or lifestyle. As a result, these associations could contribute to an improvement in one element of the simultaneity conditions required for $\mathrm{VC}$ emergence.

Further theory-building on VC emergence is required using approaches consistent with a process ontology, including process studies narrating social construction and variance studies modeling or simulating processes. A study of VC emergence that narrates social construction might focus on how different cultures and contexts construct views of time that impact the processes through which VC emerges. Economies that have experienced structural breaks that alter the view of time may be particularly fertile contexts in which to implement this research approach. Variance studies of VC emergence that model simulate processes might also build on earlier work in the application of complex adaptive systems models to entrepreneurship (McKelvey, 1997). A fuller understanding of the $\mathrm{VC}$ emergence process can ultimately contribute to a richer understanding 
of the interaction between institutions and processes at the organizational interface where new forms first appear. 


\section{TABLES AND FIGURES}

TABLE 1

A Comparison of the American, South African, and Botswana Venture Capital Models

\begin{tabular}{|c|c|c|}
\hline American VC model & South African VC model & Botswana VC model \\
\hline $\begin{array}{l}\text { Focus on technology- } \\
\text { oriented, high growth firms } \\
\text { in the seed, startup and } \\
\text { early stages }\end{array}$ & $\begin{array}{l}\text { Focus on technology- } \\
\text { oriented firms, generally in } \\
\text { the early stage }\end{array}$ & $\begin{array}{l}\text { Greater emphasis on non- } \\
\text { technology oriented firms } \\
\text { replicating technology } \\
\text { developed elsewhere }\end{array}$ \\
\hline $\begin{array}{c}\text { Fundraising-Institutional } \\
\text { investors }\end{array}$ & $\begin{array}{l}\text { Fundraising from mixed } \\
\text { sources, both public and } \\
\text { private. Limited } \\
\text { institutional investor } \\
\text { presence. }\end{array}$ & $\begin{array}{l}\text { Fundraising primarily from } \\
\text { government sources }\end{array}$ \\
\hline $\begin{array}{l}\text { Objective-maximize } \\
\text { financial returns }\end{array}$ & $\begin{array}{c}\text { Multiple objectives- } \\
\text { sustainable financial } \\
\text { returns, public policy } \\
\text { objectives }\end{array}$ & $\begin{array}{l}\text { Multiple objectives- } \\
\text { similar to South Africa }\end{array}$ \\
\hline Syndication & $\begin{array}{l}\text { Very limited syndication, } \\
\text { mainly with fund investors }\end{array}$ & Non-existent \\
\hline Staged investments & Similar to US & Little staging \\
\hline Exits via IPO, trade sale & $\begin{array}{l}\text { Exits via trade sales, } \\
\text { management buyback }\end{array}$ & $\begin{array}{l}\text { One successful exit via } \\
\text { management buyback to } \\
\text { date }\end{array}$ \\
\hline LP structure & Bewind trust & Similar to South Africa \\
\hline Intensive due diligence & Similar to US & Similar \\
\hline $\begin{array}{l}\text { Post-investment } \\
\text { monitoring }\end{array}$ & Similar to US & Similar \\
\hline $\begin{array}{l}\text { Post-investment adding } \\
\text { value }\end{array}$ & Similar to US & $\begin{array}{l}\text { Limited evidence of added } \\
\text { value }\end{array}$ \\
\hline
\end{tabular}


FIGURE 1

A Theory of Venture Capital Emergence Incorporating Coproduction

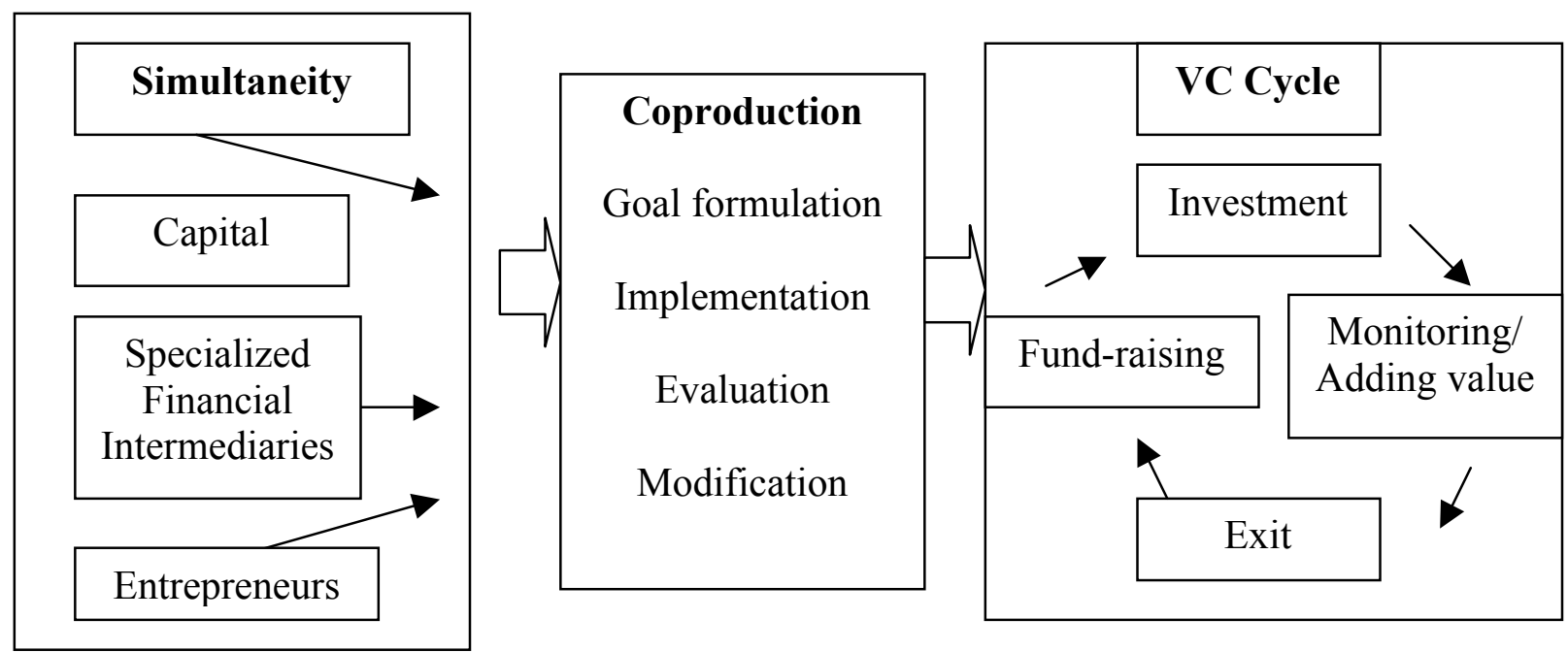

Source: Lingelbach, Murray, and Gilbert (2008) 
FIGURE 2

Private Equity and Venture Capital Funds under Management as Percentage of GDP, 2007

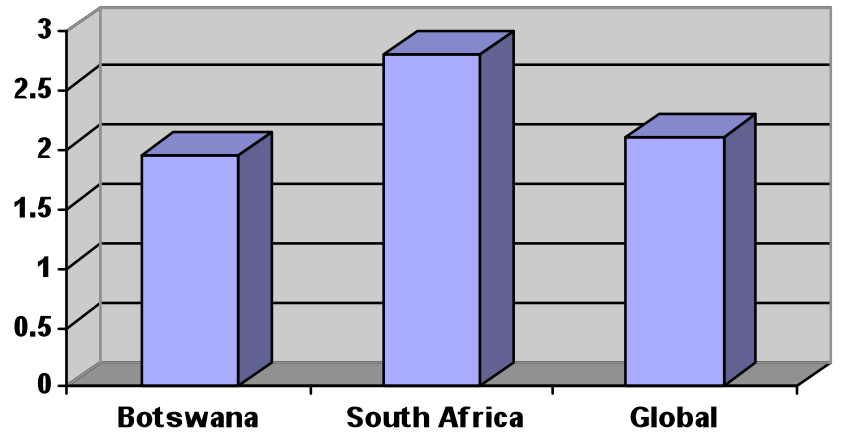

Source: KPMG/SAVCA (2008), author estimates for Botswana 
FIGURE 3

KEY MILESTONES IN BOTSWANA VC HISTORY

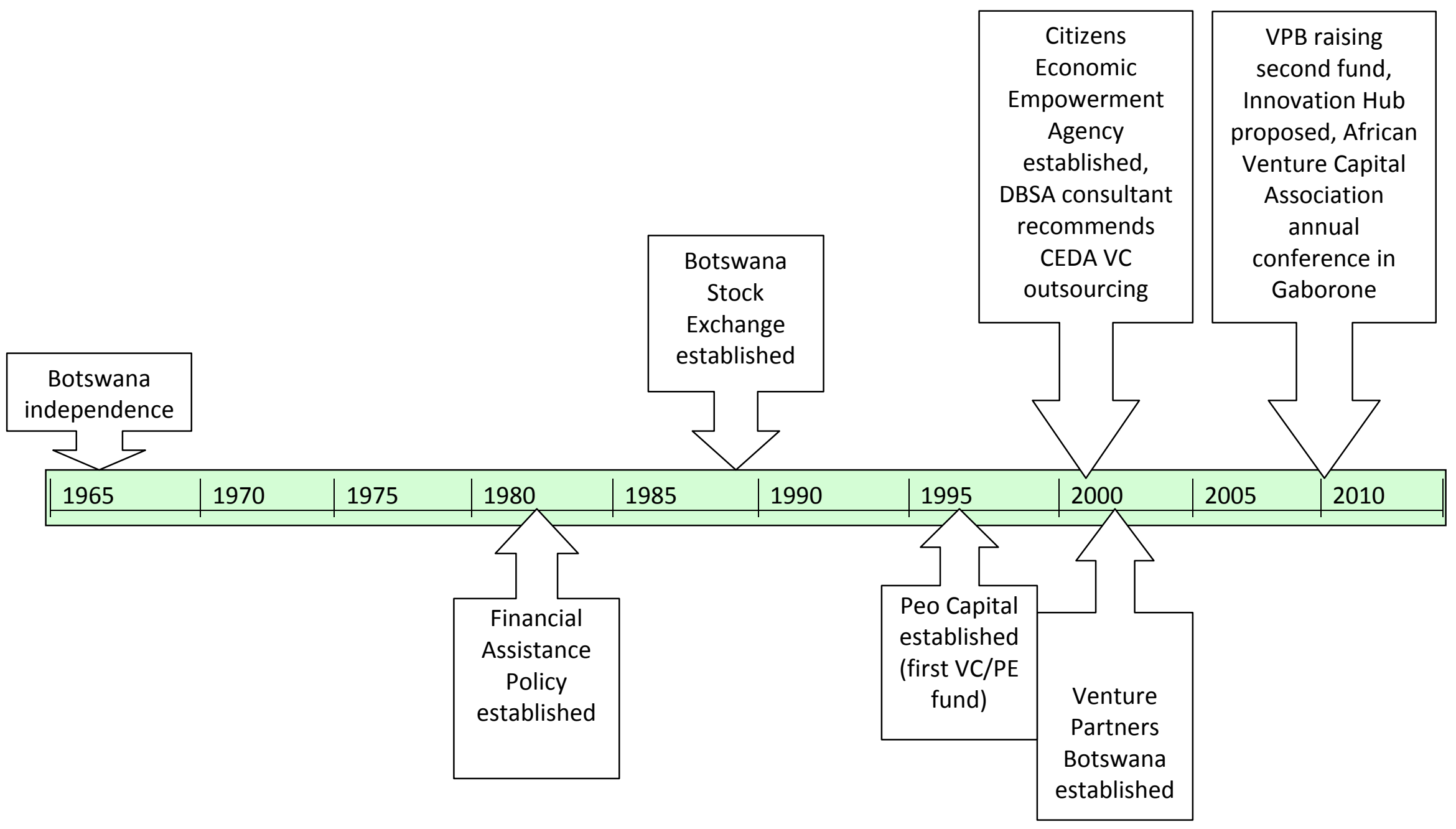


FIGURE 4

A More Complete Conceptual Model of Venture Capital Emergence

Enable

Bond

Replicate

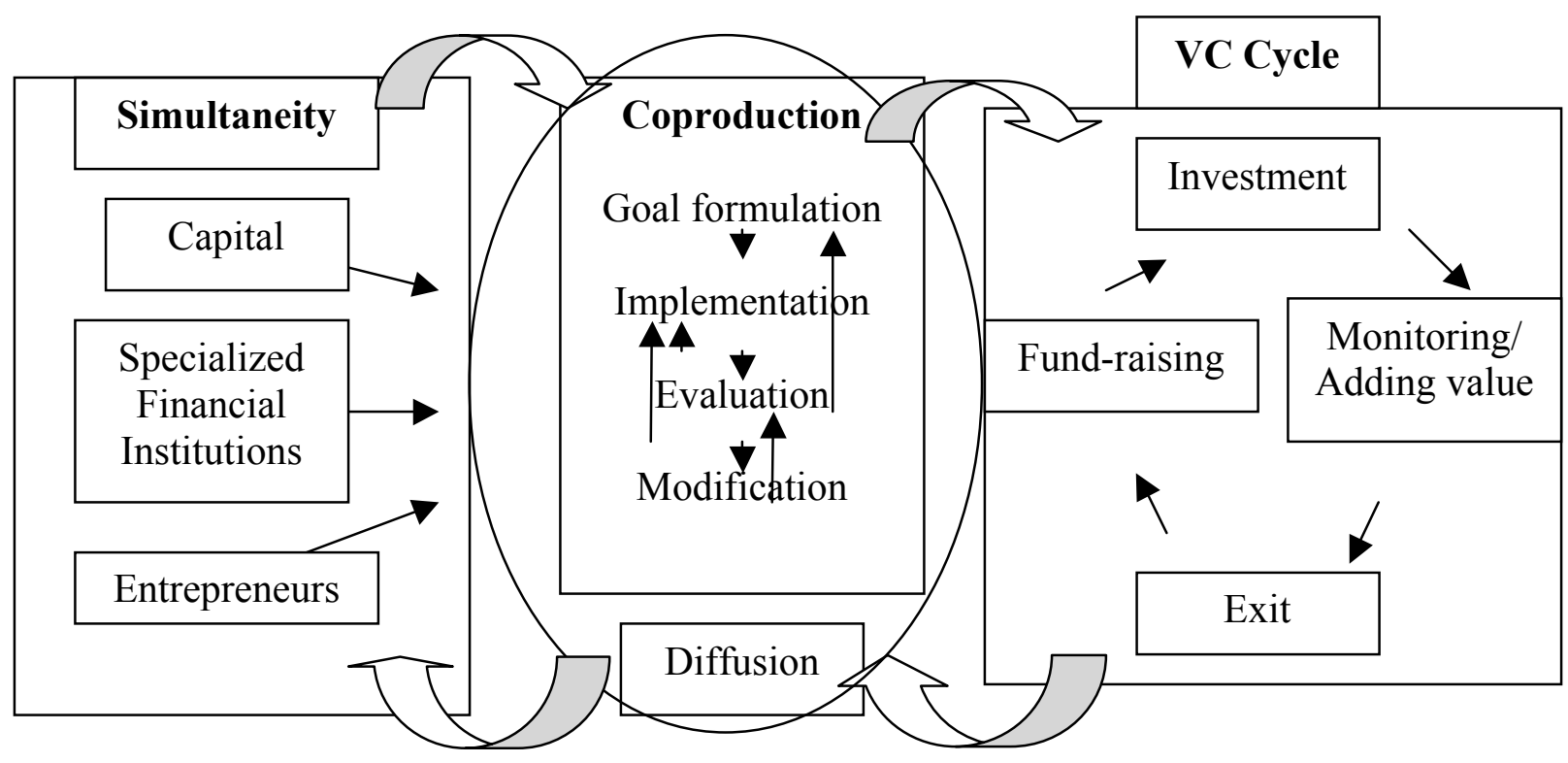




\section{REFERENCES}

Abrahamson, E. 2006. Review of Global ideas: How ideas, objects, and practices travel in the global economy. Administrative Sciences Quarterly, 51: 512-514.

Acemoglu, D., Johnson, S., \& Robinson, J. 2001. An African success story: Botswana. Discussion paper no. 3219, The Centre for Economic Policy Research, London.

African Development Bank. 2006. Botswana. Tunis: African Development Bank.

Aldrich, H. \& Ruef, M. 2006. Organizations Evolving. London: Sage.

Armendariz de Aghion, B. \& Morduch, J. 2005. The economics of microfinance. Cambridge, MA: MIT Press.

Bank of Botswana. 2008. Botswana Financial Statistics: October 2008. Accessed from: http://www.bankofbotswana.bw/article.php?articleid=2163 on December 29th, 2008.

Beaulier, S. \& Subrick, J. 2006. The political foundations of development: The case of Botswana. Constitutional Political Economy, 17: 103-115.

Botswana Ministry of Trade and Industry. 2007. Peo Venture Capital invests P29.2 million in 54 businesses. Accessed on September 2, 2008 at www.mti.gov.bw.

Burgelman, R.A. 1983. A process model of internal corporate venturing in the diversified major firm. Administrative Science Quarterly, 28: 223-244.

Chia, R. \& Langley, A. 2004. The first Organization Studies summer workshop on theorizing process in organizational research: Call for papers.

Clover, J. 2003. Botswana: Future prospects and the need for broad-based development. Pretoria, South Africa: Institute for Strategic Studies.

Coopey, R. \& Clarke, D. 1995. 3i: Fifty years investing in industry. New York: Oxford University Press.

Czarniawska, B. \& Sevón, G. (Eds.). 2005. Global ideas: How ideas, objects, and practices travel in the global economy. Frederiksberg, Denmark: Liber and Copenhagen Business School Press.

Debswana Diamond Company (Pty) Ltd. 2009. Peo Holdings. Accessed at www.debswana.com on January 9, 2009. 
Edmondson, A.C. \& McManus, S.E. 2007. Methodological fit in management field research. Academy of Management Review, 32(4): 1155-1179.

Fawcus, P. \& A. Tilbury. 2000. Botswana: The road to independence. Gaborone: Botswana Society and Pula Press.

Gaba, V. \& Meyer, A.D. 2008. Crossing the organizational species barrier: How venture capital practices infiltrated the information technology sector. Academy of Management Journal, 51(5): 976-998.

Garud, R. \& Van de Ven, A.H. 1992. An empirical evaluation of the internal corporate venturing process. Strategic Management Journal, 13: 93-109.

Gibbert, M., Ruigrok, W., \& Wicki, B. 2008. What passes as a rigorous case study? Strategic Management Journal, 29: 1465-1474.

Gilson, R. 2003. Engineering a venture capital market: Lessons from the American experience. Stanford Law Review, 55: 1067-1103.

Goetz, T. 2003. Open source everywhere. Wired, November 2003: 158-211.

Gompers, P. 1994. The rise and fall of venture capital. Business and Economic History, 23: $1-26$.

Gompers, P. \& Lerner, J. 2000. The Venture capital Cycle. Cambridge, MA: MIT Press.

Good, K. 1992. Interpreting the exceptionality of Botswana. Journal of Modern African Studies, 30(1): 69-95.

Good, K. 1993. At the ends of the ladder: Radical inequalities in Botswana. Journal of Modern African Studies, 31(2): 203-230.

Good, K. 1994. Corruption and mismanagement in Botswana: A best-case example? Journal of Modern African Studies, 32:(3), 499-521.

Good, K. 1996. Authoritarian liberalism: A defining characteristic of Botswana. Journal of Contemporary African Studies, 14(1): 29-51.

Good, K. 2002. Rethinking corruption and non-accountability in Botswana. Africa Insight, 32(3): 11-18.

Good, K. \& Taylor, I. 2005. Presidential succession in Botswana: No model for Africa, paper presented to the Department of Political and Administrative Studies, University of Botswana. 
Griliches, Z. 1957. Hybrid corn: An exploration in the economics of technological change. Econometrica, 25: 501-22.

Kenney, M., Haemmig, M., \& Goe, R. 2006. The globalization of the venture capital industry, unpublished working paper.

KPMG and the South African Private Equity and Venture capital Association. 2008.

Venture capital and private equity industry performance: Survey of South Africa covering the 2007 calendar year. Johannesburg: South African Private Equity and Venture Capital Association.

Leith, J.C. 2005. Why Botswana prospered. Montreal: McGill-Queen's University Press.

Leonard-Barton, D. 1990. A dual methodology for case studies: Synergistic use of a longitudinal single site with replicated multiple sites. Organization Science, 1: 248-266.

Lingelbach, D., Murray, G., \& Gilbert, E. 2008. The rise and fall of South African venture capital: $A$ coproduction perspective. Paper presented at International Council for Small Business World Conference, Halifax.

Lingelbach, D. \& Sherwin, H. 2008. Simultaneity or co-production in the venture capital emergence process: fund-level evidence from South Africa. Paper presented at United Nations University-World Institute for Development Economics Research Project Workshop on Entrepreneurship and Economic Development, Helsinki.

Manigart, S. 1994. The founding rate of venture capital firms in three European countries (1970-1990). Journal of Business Venturing, 9: 525-541.

Mansfield, E. 1968. Industrial research and technological innovation. New York: W.W. Norton.

McKelvey, B. 1997. Quasi-natural organization science. Organization Science, 8(4): 352-380.

Mhone, G. \& Bond, P. 2001. Botswana and Zimbabwe: Relative success and comparative failure. Discussion paper no. 2001/38, United Nations UniversityWorld Institute for Development Economics Research, Helsinki.

Mintzberg, H., Raisinghani, D., \& Theoret, A. 1976. The structure of 'unstructured' decision processes. Administrative Science Quarterly, 21: 246-275.

Mohr, L. 1982. Explaining organizational behavior. San Francisco, CA: Jossey-Bass. 
North, D., Wallis, J., Webb, S., \& Weingast, B. 2007. Limited access orders in the developing world: A new approach to the problems of development, Policy Research Working Paper 4359, Washington, DC: World Bank.

North, D., Wallis, J., \& Weingast, B. 2009. Violence and social orders: A conceptual framework for interpreting recorded human history. New York: Cambridge University Press.

Ostrom, E. 1996. Crossing the great divide: Coproduction, synergy, and development. World Development, 24: 1073-1087.

Pettigrew, A.M. 1979. On studying organizational cultures. Administrative Science Quarterly, 24: 570-581.

Picard, L. 1987. The politics of development in Botswana: A model for success? Boulder, CO: Lynne Rienner.

Rescher, N. 1996. Process metaphysics: An introduction to process philosophy. Albany, NY: SUNY Press.

Rogers, E.M. 2003. Diffusion of innovations. New York: Free Press.

Rogers, E.M. \& Kincaid, D.L. 1981. Communications networks: Toward a new paradigm for research. New York: Free Press.

Sahlman, W. 1990. The structure and governance of venture-capital organizations. Journal of Financial Economics, 27: 473-521.

Samatar, A. 1999. An African miracle: State and class leadership and colonial legacy in Botswana development. Portsmouth, UK: Heinemann Press.

Swatuk, L. 1998. Botswana: What Clinton didn't see. Southern Africa Report, 13(3): 11-14.

Taylor, I. 2006. The limits of the 'African miracle': Academic freedom in Botswana and the deportation of Kenneth Good. Journal of Contemporary African Studies, 24(1): 101-122.

Thumberg-Hartland, P. 1978. Botswana: An African growth economy. Boulder, CO: Westview Press.

Tsoukas, H. 2005. Complex knowledge: Studies in organizational epistemology. Oxford: Oxford University Press.

Tsoukas, H. \& Chia, R. 2002. On organizational becoming: Rethinking organizational change. Organization Science, 13(5): 567-582. 
Van de Ven, A. \& Poole, M.S. 1995. Explaining development and change in organizations. Academy of Management Review, 20: 510-540.

Van de Ven, A. \& Poole, M.S. 2005, Alternative approaches for studying organizational change. Organization Studies, 26(9): 1377-1400.

Venture Partners Botswana. 2008. VPB II Fund Summary. Gaborone: Venture Partners Botswana.

Werbner, R. 2002. Cosmopolitan ethnicity, entrepreneurship and the nation: Minority elites in Botswana. Journal of Southern African Studies, 28(4): 731-753.

Werbner, R. 2004. Reasonable radicals and citizenship in Botswana: The public anthropology of Kalanga elites. Bloomington, IN: Indiana University Press.

Womack, J.P., Jones, D.T., \& Roos, D. 1990. The machine that changed the world. New York: Rawson Associates.

World Bank. 2007a. An assessment of the investment climate in Botswana: Volume I. Washington: World Bank.

World Bank. 2007b. An assessment of the investment climate in Botswana: Volume II. Washington: World Bank.

World Bank. 2008. World Bank Group Entrepreneurship Survey 2008. Accessed from www.worldbank.org on January $9^{\text {th }}, 2009$.

World Economic Forum. 2008. The Global Information Technology Report 20072008. Geneva: World Economic Forum.

Zimmermann, R. \& Visser, D. 1996. Southern Cross: Civil law and common law in South Africa. Kenwyn, South Africa: Juta \& Co, Ltd. 